Histological evaluation of the zonation of colloidal gold uptake by the rat liver

Quistorff, Bjørn; Rømert, P.; Bhenke, O.

Published in:

Tissue and Cell

Publication date:

1993

Document version

Publisher's PDF, also known as Version of record

Citation for published version (APA):

Quistorff, B., Rømert, P., \& Bhenke, O. (1993). Histological evaluation of the zonation of colloidal gold uptake by the rat liver. Tissue and Cell, 25(1), 19-32. 


\title{
HISTOLOGICAL EVALUATION OF THE ZONATION OF COLLOIDAL GOLD UPTAKE BY THE RAT LIVER
}

\begin{abstract}
Keywords: Kupffer cell, liver acinus, light microscopy, ultrastructure, endocytosis, rat
ABSTRACT. The distribution and endocytotic function of Kupfer eclls in the rat liver were studied after administration of fibrinogen stabilized colloidal gold suspensions either by injection directly into the circulatory system of anacsthetized rats or by application to the isolated perfused liver. After exposure to gold particles the livers were perfused with fixative and studied using several microscopic techniques. Gold was predominantly endocytosed by a highly active population of Kupffer cells surrounding the portal spaces resulting in distinet dark patterns around the terminal portal veins. In cross-scctions of lobules the palleru appearcd as incomplete netiyorks composed of dark triangular arcas with distinct borderlines towards light areas concentric with the tcrminal hepalic veins (ccntral veins). The light areas entaincd few and relatively inactive small Kupfler cells. A wide variation of conditions gave csscntially the same uptake pattern compatible with the coneept of microcirculatory zones concentric with the terminal hepatic veins (Lamers et al., 1989; Quistorff and Rømerl, 1989), but eontradicting the traditional view of microcirculatory zones advanced by Rappaport at al. (19.54). Since the same pattcrn devcloped during conditions of anoxia, it scems that oxygen is not the stimulus for the dcvclopmental distribution of Kupffer cells with high cndocytotic actiyily. In vivo and perfusion experiments gave identical patterns, but a higlrer cndocytotic aclivity of endothelial cells was found in perfused isolated livers.
\end{abstract}

\section{Introduction}

In recent years it has been shown that hepatocytes are not a homogeneous population of cells, but differ both structurally and functionally along the length of the sinusoid (reviews by Klinger et al., 1988; Quistorff, 1990). Using the digitonin-pulse perfusion method (Quistorff and Grunnet, 1987) in order to correlate metabolic zonation with morphology we found a digitonin discoloration pattern which wc suggested was a reflection of the microcirculatory flow distribution (Quistorff and Rømert, 1989). The results obtained could not be adequately explained by the acinus (zonc) definition of Rappaport (1973; et al., 1954) and we pro-

* Anatomy Department $\mathrm{C}$, † Department of Biochemistry $A$, The Pauum Institute, University of Copenhagen, 3 Blegdamsvej. DK-2200 Copenhagen N, Denmark.

Correspondence to: P. Rømert.

Received 8 July 1992

Revised 23 October 1992 posed that the microcirculatory zones of hemodynamic equipotential were concentric with the terminal hepatic veins and not berryshaped shells conceutric with the terminal portal veins. This interpretation is in agreement with other recent reports (Lamers et al., 1989; Matsumoto et al., 1979; Teutsch, 1984, 1988). While studying the uptake of well-defined fibrinogen-gold markers by different cell types, including Kupffer cclls, we discovered that the Kupffer cells gave rise to an uptake pattern, visible on the liver surface, which was nearly identical to the diseoloration pattern we had seen earlicr applying digitonin-pulse perfusion (Quistorff and $R \emptyset$ mert, 1989). The present study elaborates on this finding and evaluates the pattern of fibrinogen-gold uptake by the Kupffer cells (and also by the endothelial cells) both in perfusion and in vivo experiments. Prcviously it was shown that Kupffer cells are more numerous around portal vein branches and that these periportal cells are larger and more active than centrolobular macrophages 
(Kaneda and Wake, 1983; Sleyster and Knook, 1982). It was further suggested by Sleyster and Knook (1982) that Kupffer cells form two cell populations which are functionally heterogeneous. The present study also investigates this aspect by different microscopic techniques. Furthermore, the gold uptake was studied in the isolated perfused rat liver as a function of flow rate, flow direction, oxygen supply and the presence of corpuscular elements in the perfusion medium.

\section{Materials and Methods}

32 male Wistar rats weighing $180-200 \mathrm{~g}$ were used. The rats were on a $12 \mathrm{hr}$ dark/light cycle, changing at 9 a.m. All animals had free access to water and food pellets. Experiments were carried out between $10 \mathrm{a} . \mathrm{m}$. and 2 p.m. The rats were anaesthetized with sodium pentobarbital $(400 \mu 1,50 \mathrm{mg} / \mathrm{ml})$ given intraperitoneally. Suspensions of 15 or $50 \mathrm{~nm}$ colloidal gold, stabilized with human fibrinogen (Sigma) following standard stabilization procedures (Behnke et al., 1986) were used as macrophage tracers. Gold conjugates were stored concentrated at $4^{\circ} \mathrm{C}$ without additives and used within one week.

Pilot experiments were performed to assess the amount of gold suspension neccssary to obtain an uptake which was readily visible on the surface of the liver. This amount which was similar in the different types of experimentation (see below) was measured spectrophotometrically $\left(\mathrm{E}_{\max }=\right.$ $535 \mathrm{~nm}$ ) and used in the experiments as the basic quantity unit, in the following called $x$. Gold suspensions were applied in the amounts: $0.5 x, 1 x, 2 x, 4 x$, and $8 x$. (The indication of the relative amounts of gold administered is more relevant with regard to the different experiments described below than giving the exact numbers measured spectrophotometrically).
The uptake of gold particles by the liver was studied in three types of experiments:

1. In vivo experiments with intact, anaesthetized rats where the different amounts of gold suspension $(0.5 x-8 x)$ were injected directly into the posterior vena cava or the portal vein using the blood of the intact circulatory system as a vehicle. After exposure periods of 30 and 60 min the liver was isolated and then conneeted to a perfusion system for a brief pcrfusion with buffer prior to fixation as described below.

2. Perfusion experiments on isolated perfused rat livers which were connected via the portal vein and the posterior vena cava to a perfusion system (perfusion technique described in detail by Quistorff, 1985; Quistorff and Grunnet, 1987). The isolated liver was perfused at $35^{\circ} \mathrm{C}$ for $10 \mathrm{~min}$ with a KrebsHenseleit (K-H) buffer (Krebs and Henseleit, 1932) equilibrated with $95 \% / 5 \% \quad \mathrm{O}_{2} /$ $\mathrm{CO}_{2}$ at a rate of $25 \mathrm{ml} / \mathrm{min}$. The different amonnts of gold suspensions $(0 \cdot 5 x-8 x)$ were diluted with $75 \mathrm{ml}$ buffer or buffer containing $20 \%$ washed bovine erythrocytes and perfused through the liver either in the direction portal vein-vena cava (antegrade perfusion) or vena cava-portal vein (retrograde perfusion). The rates of perfusion flow were: $\mathrm{K}-\mathrm{H}$ buffer: $25 \mathrm{ml} / \mathrm{min}$ and $20 \%$ bovine erythrocytes in $\mathrm{K}-\mathrm{H}$ buffer: $10 \mathrm{ml} / \mathrm{min}$. The perfusion periods were: $2,4,8,15$, and $30 \mathrm{~min}$. The uptake from the gold-K-H buffer medium was followed by measuring the concentration of gold in the medium spectrophotometrically every minute during the perfusion. In some experiments flowthrough perfusion was employed, while in others recirculation was established during the gold perfusion in order to save on the expensive gold preparations.

3. Installation experiments. In order to test a possible effect of anoxia, so-called installation experiments were carried out with gold suspensions in $\mathrm{KH}$ buffer or in $\mathrm{KH}$ buffer

Fig. 1. Liver in situ after in vivo injection of a low amount of gold snspension $(=x 1)$ into the posterior vena cava, exposure tor $60 \mathrm{~min}$, and finally perlusion with buffer and fixalive. A regular net-like pattern is seen on the surfaces of the liver lobes. The large median lobe is seen to the lelt, the left lobe to the right. FL: falciorm ligament. K: right kidney, $\times 4$.

Fig. 2. Micrograph of a lissue block from a liver after gold exposure (amount $=x 1$ ) in vivo [or $30 \mathrm{~min}$, laken through a stereo microscope. The mesothelial (intact) surface shows a regular net-like paltern of triangular areas with approaching points, $\times 14$ 

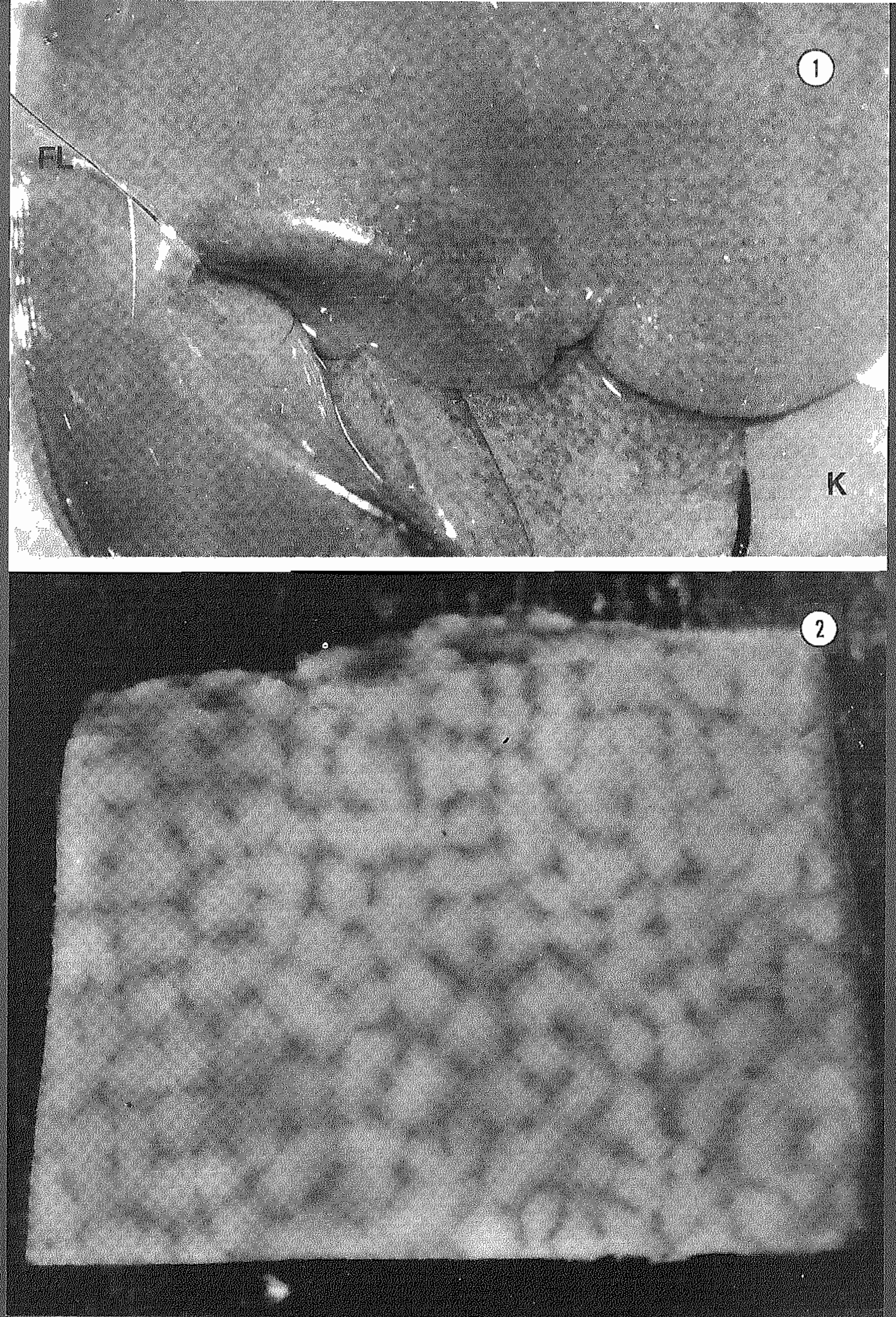
with $20 \%$ washed bovine erythrocytes which had been exposed to $95 \% / 5 \% \quad \mathrm{~N}_{2} / \mathrm{CO}_{2}$ for $1 \mathrm{hr}$. Five $\mathrm{ml}$ diluted gold suspension were injeeted via the portal vein and the inlets and outlets elosed for 4 min.

After exposure to gold the 'in vivo', 'perfusion', and 'installation' livers were perfused for $3 \mathrm{~min}$ with $\mathrm{K}-\mathrm{H}$ buffer and finally fixed by perfusion for 3 min with $2 \%$ glutaraldehyde in $67 \mathrm{mMol}$ phosphate buffer (pH $7.2 ; 4^{\circ} \mathrm{C}, 10 \mathrm{ml} / \mathrm{min}$ ) or $0.5 \%$ formaldehyde $+1 \%$ glutaraldehyde in the same buffer. Then the liver was transferred to the same fixative for $4-6 \mathrm{hr}$ and left in buffer for the following procedures.

For visualization of the liver the following methods were applied: (1) The surface of the liver was studied and photographed during and after gold uptake. (2) Tissue blocks and slices were cut by hand or with a vibratome $(100,200$, and $400 \mu \mathrm{m}$ sections $)$ and studied in a stereo microscope. Vibratome sections were dehydrated with ethanol and via xylene transferred to anise oil to make sections transparent. (3) Smaller slices of tissue (1$2 \mathrm{~mm}$ thick) were cut from both superficial and deep parts of the liver lobes, some postfixed in $1 \% \mathrm{OsO}_{4}$ for $1 \mathrm{hr}$, dehydrated and embedded in Epon 812. For light microscopy, $2 \mu \mathrm{m}$ and $8 \mu \mathrm{m}$ Epon sections were studied, some after staining with toluidine blue. For electron microscopy $400 \mathrm{~nm}$ sections were contrasted witb uranyl acetate and lead citrate.

In the in vivo experiments, spleen and bone marrow were studied to estimate the uptake of gold by the macrophages of these tissues.

\section{Results}

\section{In vivo experiments}

Injection of a colloidal gold suspension into the posterior vena cava or the portal vein resulted in a golden tinge of the liver surface gradually turning into reddish-brown. The staining was observed almost simultaneously on all lobes after a few minutes and in experiments with large dosages of gold particles reaehed its maximum after approximately $15 \mathrm{~min}$. Thus the experimentation periods of 30 and 60 min probably allowed a complete uptake of the injeeted amount of gold suspension. After isolation and removal of blood by buffer perfusion, the liver displayed the deposition of gold as a regular reddishbrown or black pattern of confluencing areas with well-defined borders towards pale brown areas (Fig. 1). Seen with the naked eye and through the stereo microscope the dark pattern was composed of triangular areas with approaching points isolating more or less eircular areas (Fig. 2). Sections of the liver showed identical patterns on cut surfaees, but also variations of this pattern depending on the direction of cutting (Fig. 3).The dark areas wcre situated around small portal vein branches including terminal portal veins, while the light areas were concentric to small and terminal hepatic veins (central veins) (Fig. 4). Blocks cut to show the transition between the mesothelial surfacc and the cut surface showed continuity of the surface pattern and the cross-section pattern (Fig. 3). Increasing the amounts of gold resulted in an accentuation and blackening of the periportal pattern, while the shape of the pattern remained unchanged with constant borders. When equal amounts (measured spectrophotometrically) were applied, $50 \mathrm{~nm}$ gold particles gave a slightly darker pattern than $15 \mathrm{~nm}$ particles. 30 and $60 \mathrm{~min}$ experiments gave identical patterns.

The stereomieroscopic examinations of cleared slices $(100,200,400 \mu \mathrm{m}$ tbick $)$ showed the same above-deseribed pattern of dark areas in a regular pattern with ratluer well-defined borders towards light areas (Figs $5,6,7,8)$. The network appeared incomplete since the points of the periportal areas

Fig. 3. Micrograph of a block from a liver ailer gold exposurc (amonnt $=x 4$ ) in vivo for $30 \mathrm{~min}$. The dark pattern is seen both on the mesolhelial and the cut surfaces. Note the continuation of the dark periportal areas at the cut edge (arrows). $\times 12$.

Fig. 4. Micrograph of a cut surface after $60 \mathrm{~min}$ exposure in vivo to a high gold dose ( $8 \mathrm{x}$ ). The dark triangular areas show well-defined borders towards pale areas surrounding terminal hepatic veins (central veius: c). $\times 50$. 


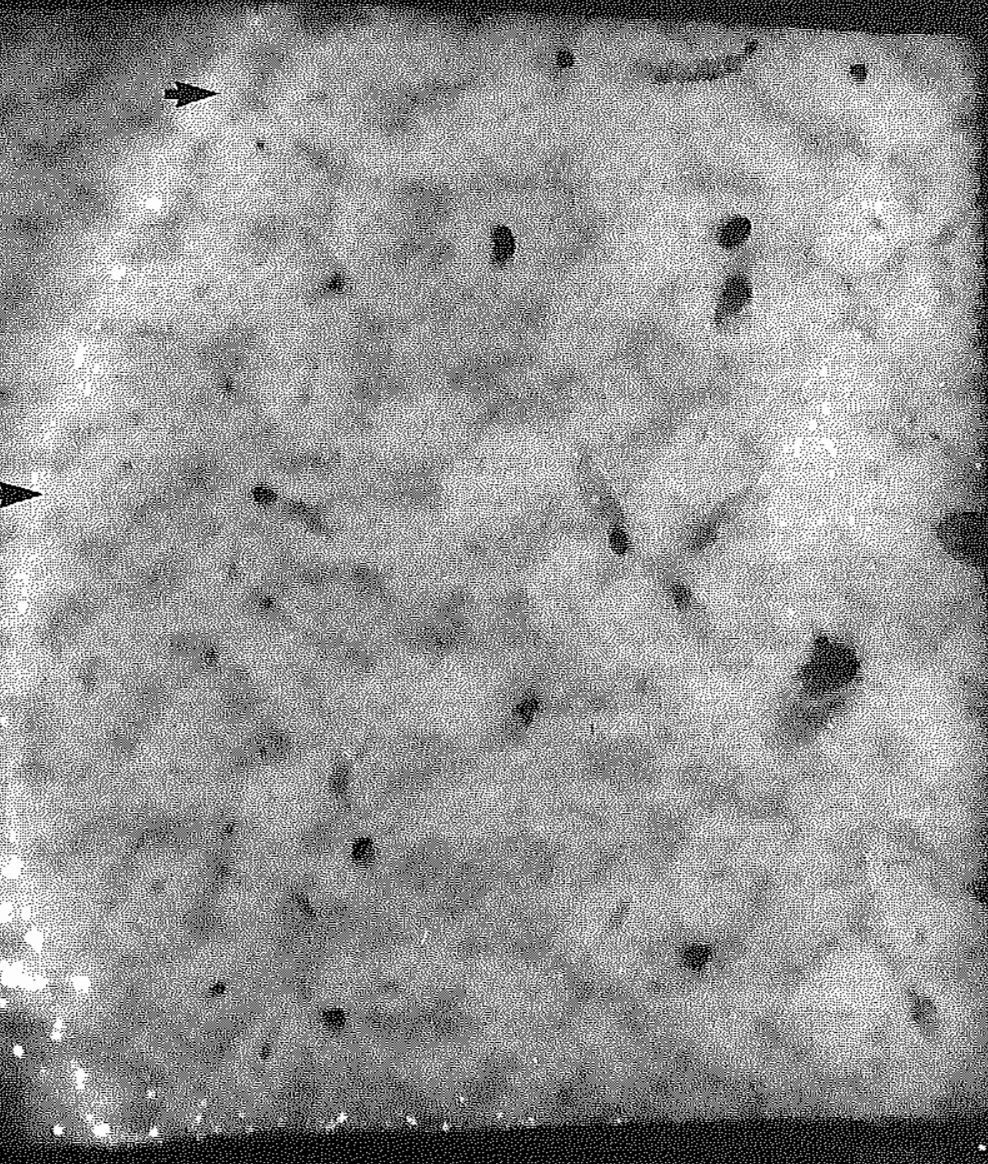

(1)

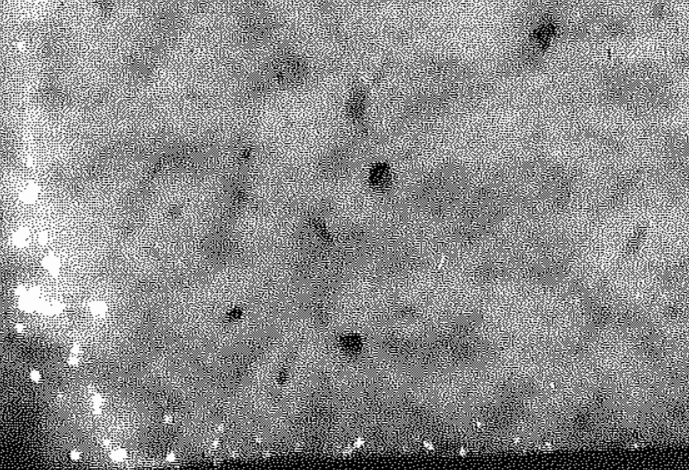

(3)
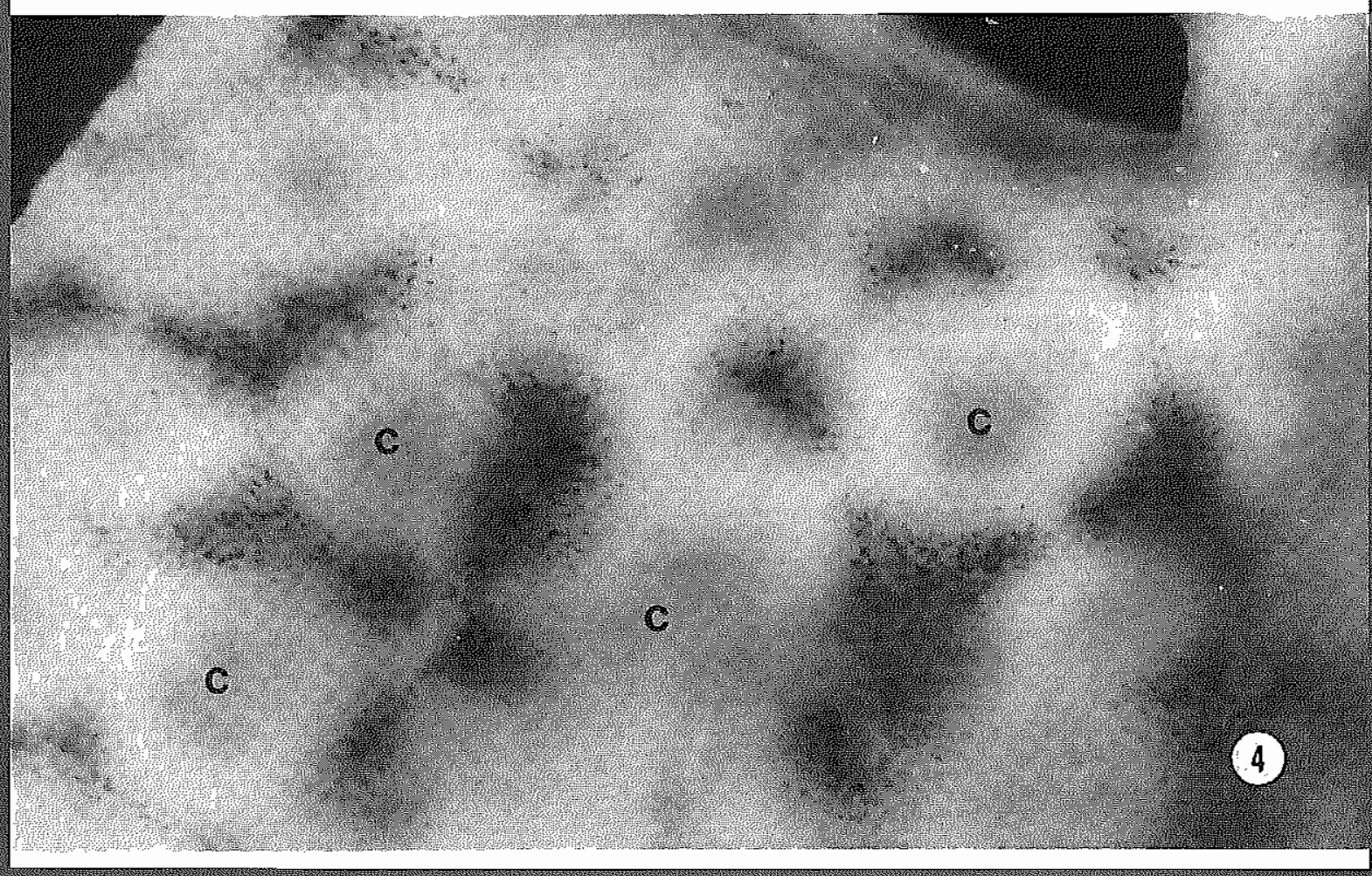
approached each other but did not fuse. The dark areas around larger $(100 \mu \mathrm{m})$ portal branches exhibited wedges of light tissue reaching the portal vcins. The shape of dark areas around terminal portal veins varied depending on the plane of section from oblong thorn-like to circular.

Light microscopy showed that the dark pattern was due to an uptake of gold by the Kupffer cells situated in the sinusoids around the portal vein branches (Fig. 9). The Kupffcr cells were found along the walls of the sinusoids, often traversing these (Fig. 10). Accumulations of gold particles appeared as smaller and larger spheres in the cytoplasm, in increasing number with increasing amount of injected gold suspension. Smaller spheres were also found in endothelial cells, often forming a regular chain of spheres (Fig. 10), being less numerous in centrolobular areas. Around the terminal hepatic veins (central veins) a few Kupffer cells containing small amounts of gold were found and the transition to the dark patteru of the gold loaded Kupffer cells in the periportal areas was strikingly abrupt.

Electron microscopy showed the periportal Kupffer cells with various endocytotic structures (sce below) containing distinct 15 and $50 \mathrm{~nm}$ gold particles. The Kupffer cells were rounded or oblong with elongated cytoplasmic processes (Fig. 11A). They were found upon the endothelium or partly between the endothelial cells forming part of the endothelial wall. They often traversed the endothelial lumen. Kupffer cell microvilli were found in close contact with microvilli of hepatocytes. The gold particles were found in: coated vesicles, tubular (worm-like) strnctures, fuzzy coat (pinocytotic) vacuoles, and secoudary lysosomes. After exposure to high doses of gold the number increased and some of the fuzzy coat vacuoles verc very large. The few centrolobular Kupffer cells contained few and small endocytotic structures.
In the endothelial cells gold particles were found in coated vesicles and larger uncoated vesicles (Fig. 11B)

Light microscopic studies of spleen and bone marrow indicated that compared to liver little gold was taken up by these organs.

\section{Liver perfusion experiments}

Perfusion of the liver with the Krebs-Henseleit buffer resulted in an evenly pale yellow liver (Fig. 12). After antegrade perfusion with gold-containing, oxygenated $\mathrm{K}-\mathrm{H}$ buffer a periportal red stained pattern developed which turned still darker until the perfused gold had been taken up (almost) completely (Fig. 13). Independent of the dosages of gold used, the pattern developed already after about 30 sec and (almost) all gold had been taken up after about 15 min. The pattern as such was independent of the amounts of gold applied and the exposure periods, aud similar to that described above in the in vivo experiments. In contrast to the in vivo experimeuts, the liver also developed a pale red staining of the areas found in the meshes of the weblike periportal pattern. The periportal uptake of gold was uniform as judged from studying the surfaces, but seemed to develop a little faster in the large median lobe. The stercoand lightmicroscopic studies showed gold uptake by many periportal and a few centrolobular Kupffer cells (Figs 14, 16, 17) as described for the in vivo experiments. These studies revealed that the pale red staining was due to a much more efficient uptake of gold by the endothclial cells, especially in the centrolobular areas (except for the inner 30 $40 \mu \mathrm{m}$ ), as opposed to the in vivo experiments. Electrou microscopy confirmed the light microscopic observations. The retrograde gold perfusions of the liver gave a periportal pattern like that of the antegrade perfusions. It was a little less distinct, probably because of an even larger uptake by centrolobular eudothelial cells. But still the

Figs 5-6. Micrographs of cleared sliccs (200 $\mu$ m thick) afier 30 min in vivo exposure to two different amounts of gold suspension (Fig. 5: $1 \mathrm{x}$; Fig. 6: $4 \mathrm{x}$ ). The regular dark patterns arc similar, but there is an aceentuation after the higher dosage. $\times 6$.

Figs 7-8. Higher magnifications of eleared slices show dark portal arcas (p) and termina portal veins ( $t$ ). Note that the points of the dark areas approach, but do not fuse. Central vein c. $\times 40$. 


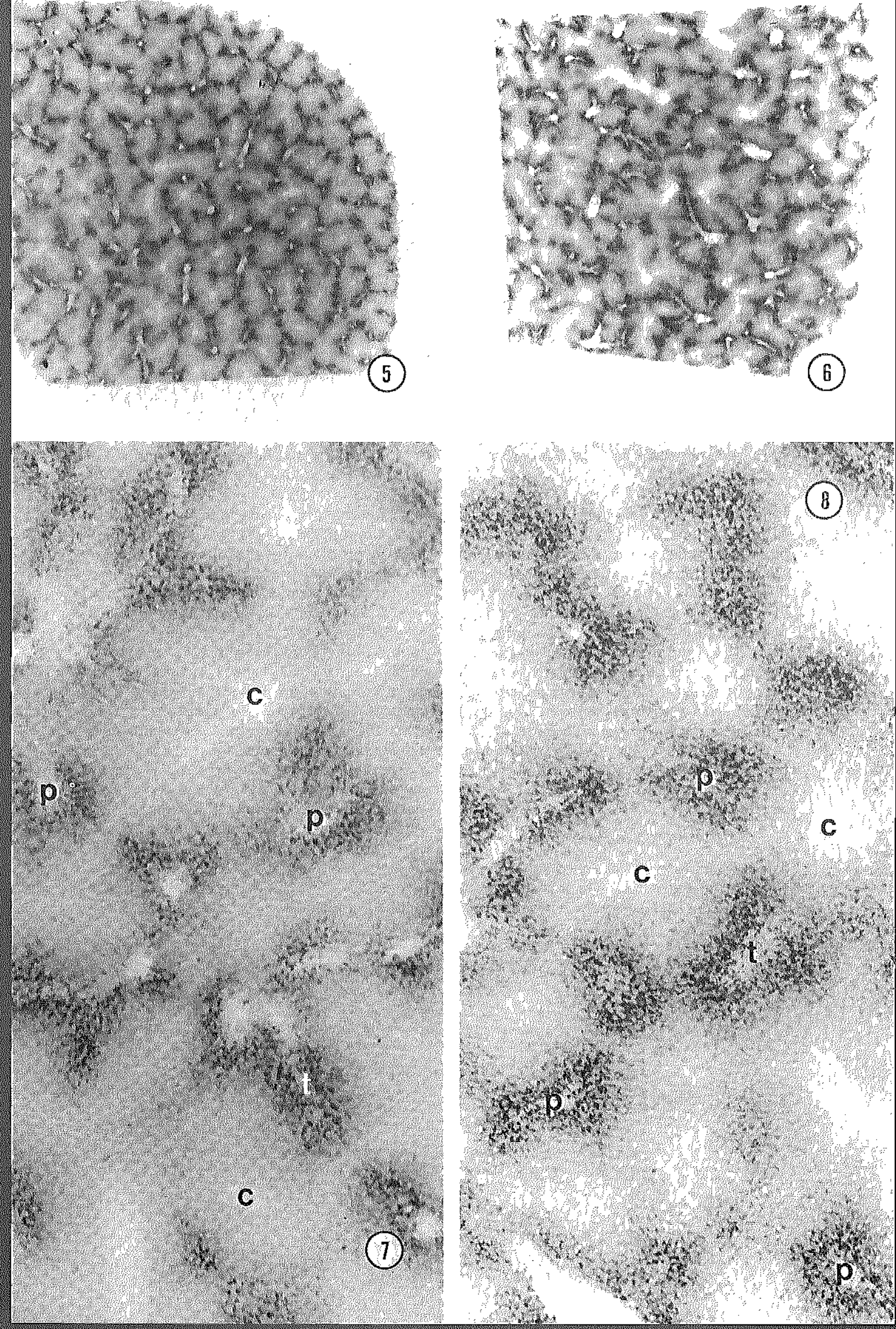


uptake by the few centrolobular Kupffer cells was moderate, like that in antegrade perfusions.

Antegrade perfusion with the gold KrebsHenseleit buffer containing $20 \%$ oxygenated erythrocytes gave results which were similar to those obtained with the gold $\mathrm{K}-\mathrm{H}$ buffer alone (Fig. 15), but the uptake by the periportal Kupffer cells was more efficient resulting in a slightly more distinct periportal pattern. The uptake by the centrolobular endothelial cells was less prominent. Thus the addition of oxygenated erythrocytes to the $\mathrm{K}-\mathrm{H}$ buffer seemed to give an antegrade uptake pattern which was intermediate in sharpncss of borders between the in vivo and the buffer perfusion patterns. When the retrograde perfusion was used, these fcatures were less evident.

\section{Installation experiments}

In order to test whether the uptake pattern of gold particles reflects the oxygen gradient along the sinusoid, experiments were performed with anoxic media installed in the liver and left without circulation for $4 \mathrm{~min}$ before fixation.The results showed the same distinct periportal uptake pattern as seen in the in vivo and perfusion experiments, thus indicating that neither the oxygen tensiou gradient nor a possible concentration gradient is decisive for the uptake pattern.

Gold particles were not found in hepatocytes in any of the above-described types of experiments.

\section{Discussion}

The present investigation shows that the distinct periportal pattern which is secn on the intact and cut surfaces of the liver after injec- tion of a gold-fibrinogen suspension into the bloodstream is due to a particularly high uptake of gold by periportally situated Kupffer cells. This pattern is remarkably similar to the pattern which was described previously in a study on the effect of digitonin-pulsc perfusion of the rat liver (Quistorff and Rømert,1989) (Fig. 18). An antegrade digitonin-pulse perfusion caused a permeabilization of hepatocytes in the afferent part of the sinusoid. This was followed by an elution of cytoplasmic matrix (cytosol), resulting in a light periportal pattern (Rømert et al., 1990). We suggested that the observed pattern reflected the flow front of the hepatic microperfusion. As discussed in detail previously (Quistorff and Rømert, 1989) this hypothesis does not harmonize with the Rappaport acinar model (Rappaport, 1973; Rappaport et al., 1954), since the demarcation lines obtained by the digitonin method form contours concentric with the terminal hepatic vein (central vein) rather than with the axis of the terminal portal vein. Recent angioarchitectural studies by Matsumoto et al. (1979) and McCuskey (1988), histochemical studies by Teutsch $(1984 ; 1988)$, and an immunohistochemical study by Lamers $e t$ al. (1989) reach the same conclusions. The Kupffer cell pattern of the present study appears identical to the patterns obtained with the above-mentioned different techniqucs. This fact suggests that the localization of the highly active Kupffer cells is defined by the natural flow distribution of the liver microcirculation. Figure 19 shows the two interpretations of the microcirculation and their relation to the Kupffer cell pattern described in this paper.

Previously it has been shown by morphologic and cndocytotic estimates that there

Fig. 9. Light micrograph of an $8 \mu \mathrm{m}$ thick unstaincd plastic scction. 60 min exposure in vivo to a high dosc of gold $(8 \mathrm{x})$. Most gold is seen in Kupffer cells surrounding a pnrtal vein branch $(p)$, wbile there is little gold around a central vein (c). $\times 230$.

Fig. 10. Light micrograph of a $2 \mu \mathrm{m}$ thick stained plastic scction. 30 min exposurc in vivo to a $4 x$ amount of gold suspension. Periportal gold containing Kupffer cells are sceu in the sinusoids along the walls and traversing. Small gold eontaining vesicles are secn in the endo. thelial cclis (arrows). $\times 1500$.

Fig. 11. A. Elcctron micrograph of a periporlal Knpifer cell after exposure in vivo to a $4 x$ amount for $30 \mathrm{~min}$. Gold particles $(50 \mathrm{~nm}$ ) are found in different endocytotic structures. $\times 5600$. B. Gold containing coatcd vesicles in an endothelial cell. $\times 15,000$. 


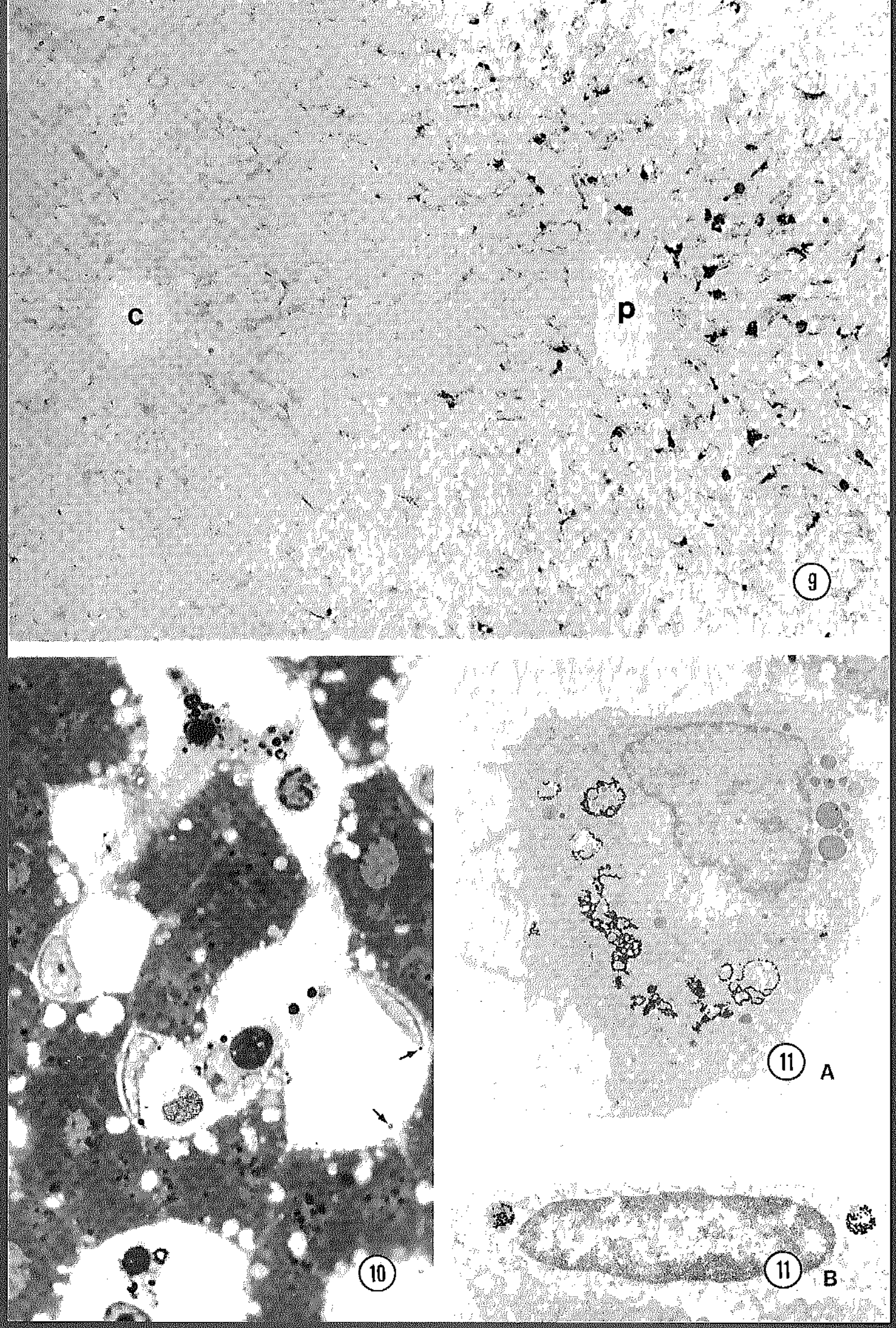


is a higher number of larger and more active Kupffer cells around terminal portal veins (defined as zone 1 of the Rappaport acinus) compared to the number, size and activity of Kupffer cells around terminal hepatic veins (Sleyster and Knook, 1982; Bouwens et al., 1986). It has also been suggested by the same authors that the Knpffer cells do in fact form two subpopulations which differ in morphology and activity. That the Kupffer cell population is morphologically and functionally heterogeneous is strongly supported by the present study, since we found little uptake of gold by the few small Kupffer cells identified by light and electron microscopy in the centrolobular (perivenous) area, regardless of the route in which gold is presented. The accentuation of the periportal pattern with unaltered shape when dosages of gold are increased agrees with the findings of Sleyster and Knook (1982) and Bouwens et al. (1986) which showed a relatively higher uptake of latex particles by periportal Kupffer cells even at overloading doses.

The liver perfusions with an oxygenated $\mathrm{K}$ $\mathrm{H}$ buffer containing fibrinogen-gold particles resulted in periportal Kupffer cell patterns like those obtained in the in vivo experiments, with antegrade and retrograde perfusions, and with and without recirculation. This confirms that the major uptake is by a periportal population of very active Kupffer cells. However, a certain amount of gold is taken up by endothelial cells and found in vesicles which are localized in the sparse flattened cytoplasm. This rather diffuse uptake does not disturh the dominant Kupffer cell pattern, but gives a weak background staining. The higher endothelial uptake by perfusion compared to that in vivo might at least partly be explained by the higher flow rate $(25 \mathrm{ml} / \mathrm{min}$ versus $10 \mathrm{ml} / \mathrm{min})$, but also the absence of corpuscular elements could be of importance (see below). The higher uptake found by retrograde perfusions (compared to antegrade perfusions) may be explained by higher concentrations of gold at the inlet. Also high doses seem to increase the endothelial uptake. These observations probably indicate that the kinetics of endocytosis are different not only for the snbpopulations of Kupffer cells, but also for Kupffer cells and endothelial cells. Recently te Koppele et al. (1990) using a light guide teclinique on the intact liver surface found that the rate of carbon uptake was reversed from perivenous (centrolobular) regions to periportal when an antegrade perfusion was shifted to a retrograde perfusion. Assuming that gold and carbon are treated alike, the apparent disagreement with the present study could be explained by the possibility that they first measure a perivenous endothelial uptake in the antegrade perfusions. Their published photos of antegrade perfusions (Figs 6 a, b. te Koppele et al., 1990) show a considerable uptake of carbon by endothelial cells, as well as Kupffer cells.

The addition of bovine erythrocytes (20\%) to the Krebs-Henseleit buffer gave an uptake more like that of the in vivo experiments. Since this addition claims a reduction of flow ratc $(25 \mathrm{ml} / \mathrm{min}$ to $10 \mathrm{ml} / \mathrm{min})$ it is difficult to estimate if the uptake is influenced by rate of flow or presence of erythrocytes or both. The installation experiments with anoxia seem to indicate that neither the oxygen tension nor a possible concentration gradient is decisive for the difference in uptake by periportal and perivenous Kupffer cells. This is also supported by the observations that retrograde perfusion with buffer $+20 \%$ erythrocytes gives a distinct periportal pattern.

Considering the fact that the gold particle uptake pattern resembles the digitouin-cell

Figs 12-13. Isolated liver after the initial perfusion with buffer (Fig. 12) and after exposure to a high dose (4x) of gold suspension for 15 min (Fig. 13). The light yellow blood-empty liver develops a periportal pattern with a lighter background staining. $\times 3$.

Figs 14-15. Micrographs of cleared slices alter perfusions with gold suspcnsions (2x) in KrebsHenseleit buffer (Fig. 14) and in Krebs-Henseleit bnffer containing 20\% erythrocytes (Fig. 15). There is a higher uptake by periportal Kupffer cells and a smaller uplake by centrolobular endothelial cells witb $20 \%$ erythrocytes, indicated by a more pronounced difference in staining. $\times 40$. 


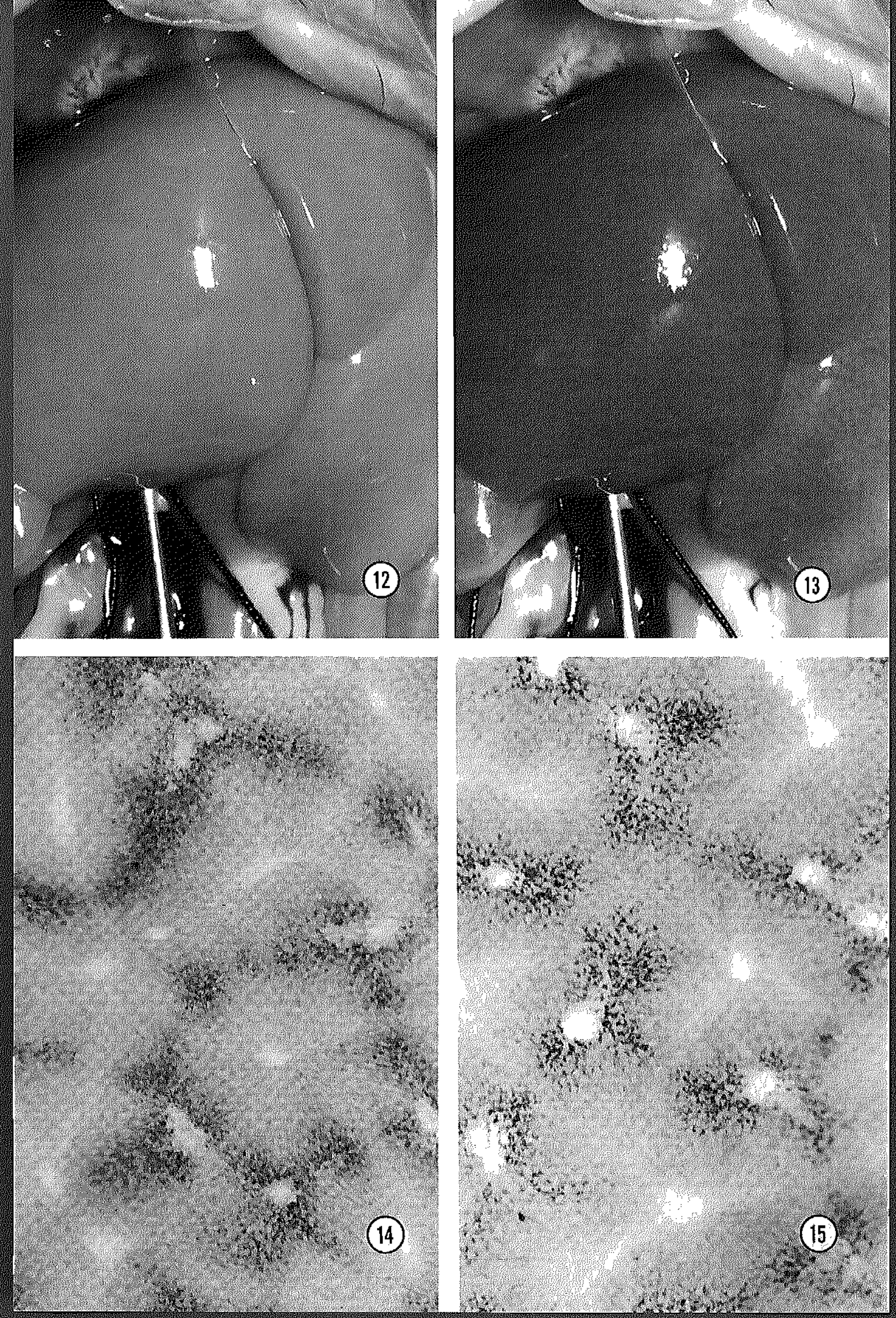




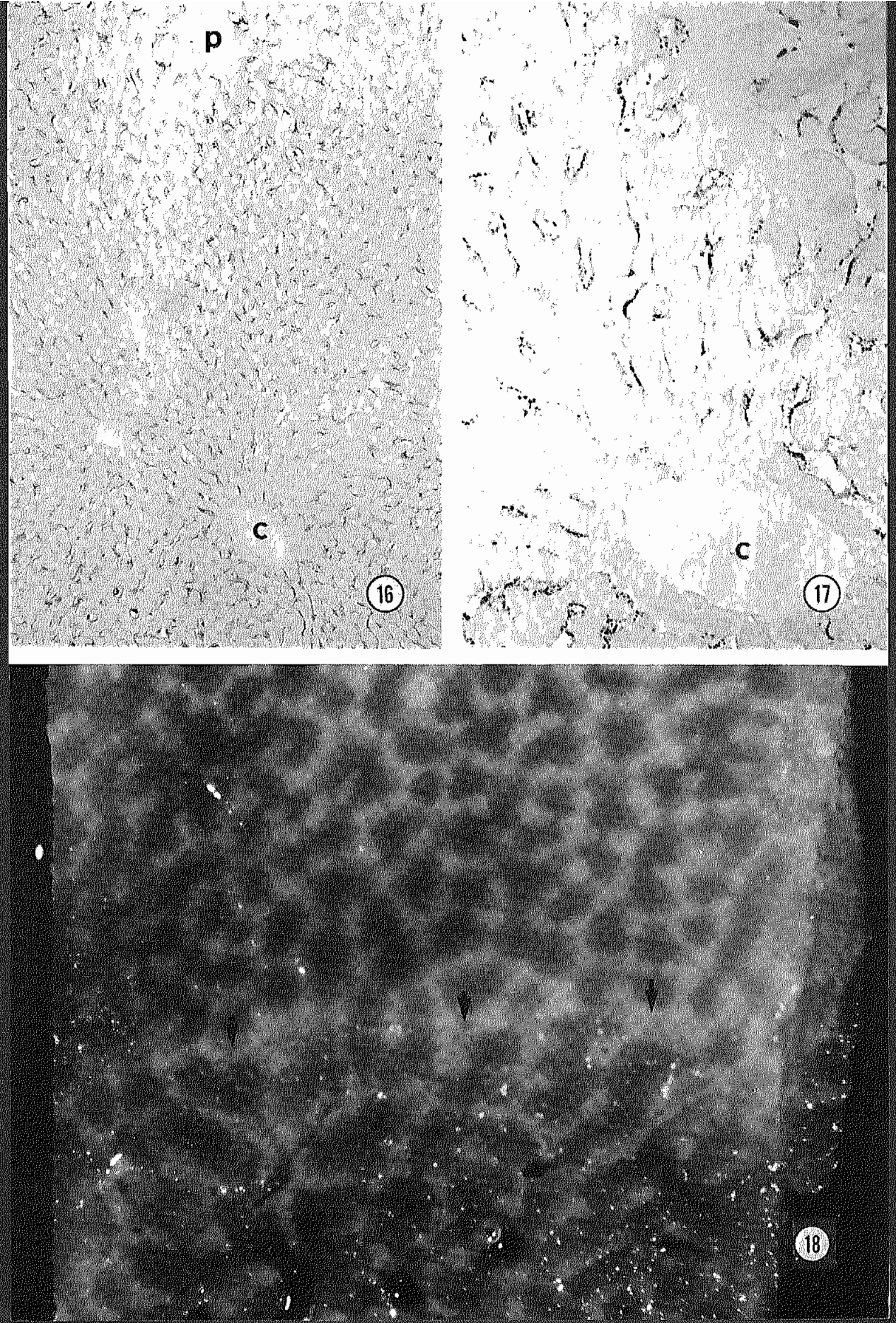




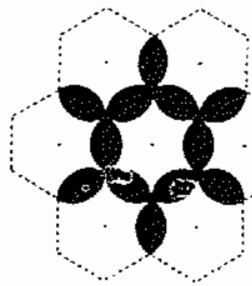

A

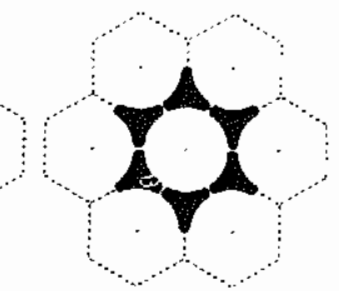

B
Fig. 19. Schematic drawings of liver lobules cut in the plane of the termiual portal vein and perpendicular to the tcrminal bepatic ycin (ccntral vein). 19A shows the zonc1 pat1crn according to the Rappaport model of the liver microcirculation. 19B shows the correspondiug paltern in accordauce with our interpretation of the microcirculation (as expressed in Fig. 18) assuming hemodynanic zoues concentric with the terminal hepatic veins (central veius) Note that the distribntion pattern of the highly active periportal Kupffer cells (Fïgs I-8, 13, 14) is similar to that iudicated in Figure 19B.

permeabilization pattern, it is important to realize the basic difference between the two processes: assuming even distribution of cholesterol in hepatocyte membranes along the sinusoids, the digitonin pattern arises as a consequence of a certain amount of digitonin (equivalent to the same molar amount of cholesterol) being distributed by the microcirculation. The gold uptake pattern, on the other hand, reflects one or both of the following factors: (1) Actual physical location of a certain population of Kupffer cells restricted to the area of the pattern and (2) uptake dependent on the dynamic distribution of gold by the microcirculation. The fact that the Kupifer cell labelling pattern remains the same with antegrade and retrograde perfusions; the fact that it is largely independent of flow rate, amount of gold and oxygen tension strongly suggests that the macrophages taking up (endocytosing) gold are indeed selcetively located in the area in which the pattern develops. This is quite unlike the digitonin distribution, which was found to correspond very closely to flow direction and amonnt of digitonin. Thus, the digitonin pattern created in pulse perfusion experiments reflects the distribution of the perfusion front, while the gold uptake pattern simply maps the location of Kupffer cells with a high capacity for gold uptake. The gold uptake by endothelial cells ou the other hand, seems to be more dependent on rate and direction of flow and (to some degree) on the amount of gold. Consequently the endothelial cells could perhaps be used as an indicator of the flow distribution, as indeed is the case for digitonin. However, it would appear that the uptake speed of gold is mucl too slow for such an indicator function, and therefore the distribution pattern of gold uptake in endothelial cells must be reflecting concentration gradients rather than flow front distribution.

In conclusion, it can be stated that the periportal Kupffer cells form a functionally distinct population situated in a periportal zone concentrie with the terminal hepatic vcins (central veins). In our interpretation the zone does not correspond to that of the Rappaport acinus (zonc 1), but rather to that found after antegrade digitonin-pulse perfusions. In vivo and perfusion experiments seem mostly to differ as far as the uptake by endothelial cells is coucerned.

\section{Acknowledgements}

The authors wish to thank Ms Lissi Immerdal, Ms Marianne Juhl-Christensen, and $\mathrm{Mr}$ Kjeld Stub-Christensen for skilfull technical assistance.

Figs 16-17. Light micrographs of $8 \mu \mathrm{m}$ thick unstained plastic sections alter $10 \mathrm{~min}$ exposure to a gold-buffer medjum (4x). There is a high uptake in endothehial cells of all parts of the lobule. portal space: p. central vein: c. Fig. $16 \times 120$; Fig. $17 \times 380$.

Fig. 18. Micrograph of a liver block after a porta-eava digitouin perfusion. Notc the regular net-like pattern of light, affeetcd tissue on the mcsothelial and cut surfaces with continuation at the cut cdge (arrows). Counpare with Figs 2 and $3 . \times 12$. 


\section{Reference}

Befnke, O., Amnitzbøll, T., Jessen, H., Klokker, M., Nilausen, K., Tranunı-Jensen, J. and Olsson, L. 1986. Nonspecific binding of protein-stabilized gold sols as a sontec of crror in inımunocytocheınistry. Eur. J. Cell Biol., 41, $326-338$.

Bouwens, L., Backcland, M., dc Zanger, R. and Wissc, E. 1986. Quantitation, tissue distribution and proliferation kinelics of Kuplfer cells in normal rat liver. Hepatology, 6, 718-722.

Kaneda, K. and Wakc, K. 1983. Distribution and morpbological characteristics of the pit cells in the liver of the rat Cell Tissue Res., 233, 485-505.

Klinger, W., Devereux, Th. and Fouts. J. R. 1988. Functional and structural zonal hepatocyte hetcrogencity-dynamics and ontogenic developnent. Exp. Pathol, 35, 69-91.

Krebs, H. A. and Henscleit, K. 1932. Untersuchungen über die Harnstofibildung im Tierkörper. Hoppe-Seylers Z. Physiol. Chem., 210, 33-66.

Lamers, W. II., I Iilberts, A., Furt, E., Smith, J., Jonges, G. N., van Noorden, C. J. F., Gaasbcek Janzen, J. W., Charles, R. and Moorman, A. F. M. 1989. Hepatic cuzymic zonation: A recvaluation of the concept of the liver aejusus. Hepatology, 10, 72-76.

Matsumoto, T., Komori, R., Magara, T., Ui, T., Kawakami, M., Tokuda. T., Takasaki, S., Hayashi, H., Jo, K., Hano, H., Fnjino, H. and Tanaka, H. 1979. A study of the normal structure of the human liver, with special refere ice to its angioarchitecture. Jikeikai Med. J, 26, ]-40.

McCuskey, R. S. 1988. Hepalie microcirculation. In Sinusoids in hman liver: health and disease (eds. P. Bioulac-Sagc and C. Balaboud), pp 151-164. The Kupffer Ccll Foundation, Amsterdau.

Quistorff, B. 1985. Gluconeogeuesis in periportal and perivenous hepalocytcs of ral liver, isolated by a new high-yicld digitonin/collagenase perfusion techuiquc. Biochem. $J ., 229,221-226$.

Qnistoril, B. 1990. Metabolic heterogeneily of liver parenchymal cells. Essays Biochem., 25, 83-136.

Quistorff, B. and Gnunct, N. 1987. Dual-digitoniu-pulse pcrfusion. Biochem. J., 243, 87-95.

Quistoril', B. and Rømerl, P. 1989. Iligh zoue-seleclivily of cell perneabilization lollowing digitonin-pulse perfusion of rat liver. Histochemistry, 92, 487-498.

Rappaport, A. M. 1973. The inicrncirculatory hepalic nnit. Microvasc. Res., 6, 212-228.

Rappaport, A. M., Borowy, Z. J., Lougheed. W. M. and Lotlo, W. N. 1954. Subdivision of hexagonal liver lobules into a structnral and functional unit. Anat. Rec., 119, 11-33.

Rømerl, P., Matthiessen, M. E. and Quistorlf, B. 1990. U/trastructural changes of Jiver parenchyına following digitonin-pnlse perfnsion of rat liver. Cell Tirsue Res., 261, 42:-430.

Sleyster. E. Cl. and Knook, D. L. 1982. Relation between localization and Iunction of rat liver Kupffer cells. Lab. Invest., 47, 484-490.

tc Koppelc, J. M. and Thnrman, R. G. 1990. Phagocylosis by Kupffer cells predominales in pericentral regions of the liver lobulc. Ain. J. Physiol., 259, G814-G821.

Tcntsch, H. F. 1984. Sex-specific regionality of liver metabolism during statvation; with special reference to the heterogeneity of the lobnlar periphery. Histochemistry, 81, 87-92.

Tentsch, H. F. 1988. Regionality of glncosc-6-phosphate hydrolysis in the liver lobule of the rat: metabolic heteroggeneily ol portal and septal sinusoids. Hepatology, 8, 311-317. 